\title{
超臨界流体抽出法の香料への応用
}

\author{
奥 村 烝司 \\ 長谷川香料株式会社川崎研究所 \\ （川崎市中原区荻宿 335）
}

\section{Applications of Supercritical Fluid Extraction \\ to Flavors and Fragrances Materials}

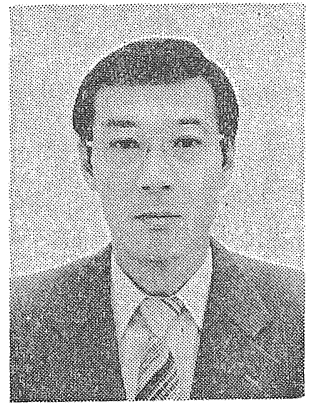

\section{Joji OKumura}

Kawasaki Research Center, T. Hasegawa Co. Ltd.

(335, Kariyado, Nakahara-ku, Kawasaki)

\section{1 はじめに}

超臨界ガス抽出法は, 近年さまざまな分野への応用が 研究されてきている。超臨界ガス抽出では, ガスの種類 の選択により比較的常温に近い温度下でも操作が可能で あり，天然物から熱に敏感な物質の抽出に有利であると されている。

従来，天然原料からの香料物質の調製は，主に水蒸気 蒸留法, 溶刋抽出法により行われているが，これらの方 法による場合，香料物質が熱により変化するおそれのあ ること，抽出物より溶剤を完全に除去するのに伴い，一 部の香気成分が失われるなどの問題点がある。このため 超臨界ガス抽出プロセスを香料関連物質の抽出に利用し ようとする試みがなされてきた。

香料関連物質の超臨界ガス抽出に用いられる溶剤ガス はほとんど二酸化炭素に限られている。これは二酸化炭

表-1 二酸化炭素の溶剤特性

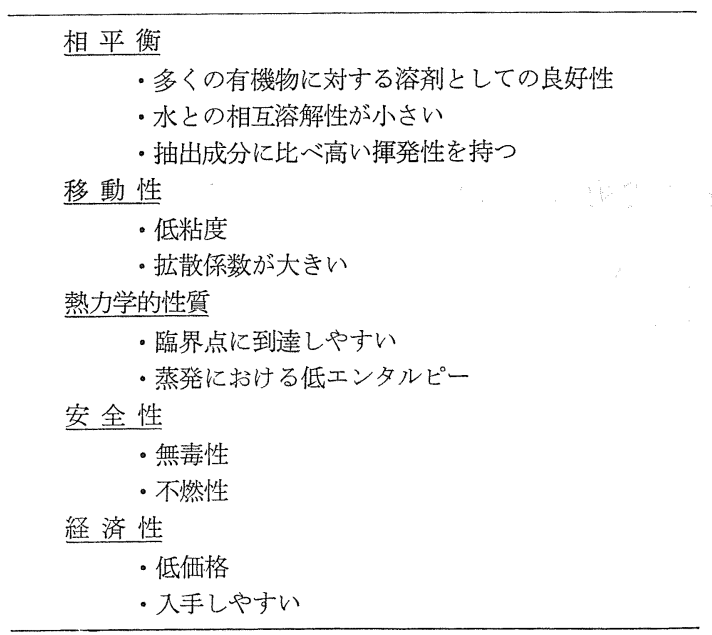

素の臨界点が $73.8 \mathrm{bar}, 31.1^{\circ} \mathrm{C}$ であり, 比較的温和な 条件下で超臨界状態となり, また安全性も高いためであ る。表-1 に二酸化炭素の溶剤特性1を示した。 超臨界二酸化炭素抽出法の香料関連物質抽出への応用 はこれまで種々の対象に検討されてきており，その一部 を表-2に示した。主な対象はホップ,スパイスであり， その他フルーッ, コーヒー, 茶の香気成分の抽出む試み られている。また超臨界ではなく液体二酸化炭素による これらの詨象物からの香気成分の抽出もいくつか検討さ れている。香料関連物質の対象によっては液体二酸化炭 素によっても効率のよい抽出が達成される場合がある。 以下, 超臨界及び液体二酸化炭素を用いて検討されて

表-2 超臨界及び液体二酸化炭素による香料 関連物質の抽出例

\begin{tabular}{|c|c|c|}
\hline 抽出対象天然物 & 抽 出 成 & 条 件 \\
\hline 果汁, エッセンス & $\begin{array}{l}\text { アルコール, エステル, アル } \\
\text { デヒド, ケトン }\end{array}$ & SC. Liq. \\
\hline ペッパー & 精油, ピペリン & SC. \\
\hline チリペッパー & 精油, カプサイシン & SC. \\
\hline ク & 精油，オイゲノール & SC. \\
\hline シナモン & $\begin{array}{l}\text { 精油, シンナミックアルデヒ } \\
\text { ，オイゲノニル }\end{array}$ & SC. \\
\hline ナツ メ グ & 精油，トリミリスチン & SC. \\
\hline ジンジャー & 精油 & SC. Liq. \\
\hline ピメントベリー & 精油, オイゲノール & SC. \\
\hline バニラビーンズ & 精油, バニリン & SC. \\
\hline ジュニパベリー & 精油 & Liq. \\
\hline ライラックの花 & 精油, ベンジルベンゾエート & SC. \\
\hline 木 ッ $7^{\circ}$ & 精油, $\alpha$-酸 & SC. Liq. \\
\hline ワ イ ン & エステル, アルコール & Liq. \\
\hline$コ ー ヒ-$ 豆 & 香気成分 & SC. Liq. \\
\hline 茶葉 & 香気成分 & SC. Liq. \\
\hline
\end{tabular}

* Liq. : 液体 $\mathrm{CO}_{2}$ 抽出

* SC. : 超臨界 $\mathrm{CO}_{2}$ 抽出 
きた香料関連物質抽出の応用例をいくつか紹介する。

\section{2 ホップの抽出}

ホップはビールに特有の香気，爽快さ，苦味を与える のに必要であり，その有効成分は精油と， $\alpha$-酸（フムロ ン)， $\beta$-酸（ルプロン）からなるソフトレジンと称され る物質である。ソフトレジンは，ホップのエーテル抽出 で得られるものをさし，ビール特有の苦味の付与に重要 な役割をはたしている。また非極性溶剤に不溶な樹脂分 はハードレジンと呼ばれ，ホップの収穫後時間が経つに つれてソフトレジンからハードレジンへ転換する。

ホップエキスは従来，ヘキサン，塩化メチレン，メタ ノールなどを用いて抽出されてきたが, 抽出物には有効 成分である精油，ソフトレジンのほか，ハードレジン， タンニン, 脂肪， ワックス及び色素成分も多く，暗緑 色〜黒緑色の物質であり，また残存溶剂除去の問題もあ る。これに対し超臨界または液体二酸化炭素抽出では残 留溶剂の問題もなく, ホップの有効成分が効率よく抽出 される。

表-3 ${ }^{2)}$ にホップの超臨界二酸化炭素抽出物と市販のホ ップエキスの組成を示した。超臨界二酸化炭素抽出物の 組成は, 溶剤抽出による市販ホップエキスのものと類似 しており， $\alpha$-酸の抽出率は $99 \%$ にも達している。超臨 界二酸化炭素抽出物はオリーブグリーンのペーストで, ホップの特徵的な香気を有している。

ホップの液体二酸化炭素抽出物は 表-4 ${ }^{32}$ に示すよう に，ハードレジンをほとんど含まず，精油， $\alpha$-酸に富ん

表-3 ホップの超臨界二酸化炭素抽出

\begin{tabular}{|c|c|c|c|c|c|}
\hline & \multicolumn{2}{|c|}{$\hat{\mathrm{CO}}_{2}^{2}$ 抽出 } & \multirow{2}{*}{$\begin{array}{c}\mathrm{CO}_{2} \\
\text { 抽出物 }\end{array}$} & \multirow{2}{*}{ 抽出率 } & \multirow{2}{*}{$\begin{array}{l}\text { 市 販 } \\
\text { ホップ } \\
\text { エキス }\end{array}$} \\
\hline & （前） & （後） & & & \\
\hline 水 分 含 量 $(\%)$ & 6.0 & 5.4 & 7.0 & & 8.0 \\
\hline トータルレジン $(\%)$ & 30.3 & 4.3 & 90.0 & 89.9 & 88.5 \\
\hline ソフトレジン $(\%)$ & 26.6 & 1.3 & 84.8 & 96.5 & 82.0 \\
\hline$\alpha$-酸 （\%) & 12.6 & 0.2 & 41.2 & 98.9 & 39.5 \\
\hline$\beta$-酸 $\quad(\%)$ & 14.0 & 1.1 & 43.6 & 94.4 & 42.5 \\
\hline ハードレジン $(\%)$ & 3.7 & 3.0 & 5.2 & & 6.5 \\
\hline
\end{tabular}

表-4 ホップの液体二酸化炭素抽出物の組成 (イギリス, オーストラリアでの $)$

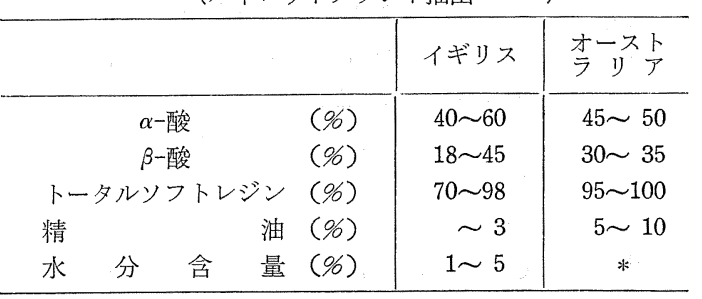

* 組成比は乾物重量換算
でおり，超臨界条件での抽出に比べより選択的にホップ の有効成分が抽出されている。液体二酸化炭素によって も $\alpha$-酸の抽出率は $96 \%$ 程度にまで達する

ホップを液体二酸化炭素または $40^{\circ} \mathrm{C}$ 以下での超臨界 二酸化炭素抽出を実施すれば，二酸化炭素による不溶性 ガス雰囲気下で抽出されることとあいまって，ホップの レジン成分は酸化などの化学的変化を起こさずに抽出さ れ，香気成分も原ホップ中に存在していたものが再現よ く抽出される。図-1（a）は原料のホップペレット，図一 1 (b) は超臨界二酸化炭素抽出物の精油の含酸素画分の ガスクロマトグラムである。両者のパターンはきわめて 類似しており，抽出中に何らの成分変化も起こっていな いことが示されているら。

超臨界二酸化炭素によるホップ抽出物には栽培時に使 用される農薬も含まれず，さらに二酸化炭素抽出物は抽 出から充てんまで不活性ガス雾囲気下で行われるため, かなりの期間貯蔵でき，有機溶剂抽出物のように低温貯 蔵は必要でないとも言われている5)。

\section{3 スパイスの抽出}

スパイスは，一般的に香気に関与する精油分と呈味成 分の両者を含んでおり，スパイス抽出物としてはそれら 両者を含んでいることが必要である。スパイス抽出物は 乾燥, 粉砕されたスパイス原料に比べ微生物污染の心配 のないこと，品質が安定しているなどの利点をもってい る。スパイスの超臨界二酸化炭素抽出では, 原料のもつ フレーバー特性が効率よく抽出され，かつ残留溶剤の問

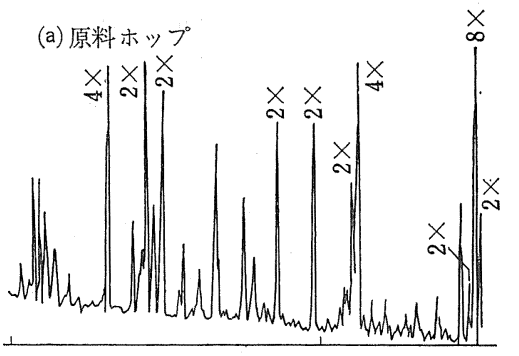

(b) 超臨界二酸化炭素抽出物

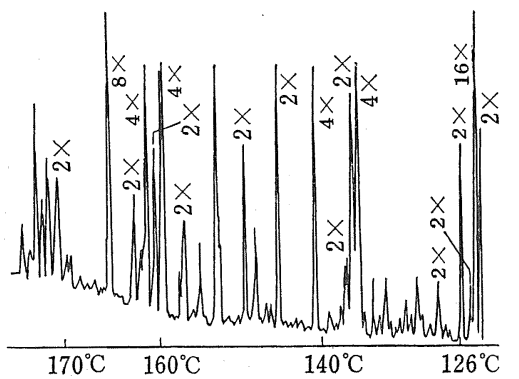

図-1 原料ホップ及び超臨界二酸化炭素抽出物中の 精油の含酸素画分のガスクロマトグラム ${ }^{5)}$ 
題のない抽出物が得られる。

表-52) にはペッパー，ナツメグ，チリーの超臨界二酸 化炭素抽出物の組成を示した。いずれの場合にも二酸化 炭素抽出物の組成は塩化メチレン抽出物ときわめて類似 していた。ペッパー，ナツメグでは精油分がそれぞれ $81 \% ， 99 \%$ とかなり效率よく抽出されており，またぺ ッパー，チリーそれぞれの辛味成分であるピペリン，カ プサイシンもほぼ 100\% 抽出されている。またペッパ 一，ナツメグの超臨界二酸化炭素抽出物は塩化メチレン 抽出物より淡色であり, 香味に関与しない色素成分は抽 出されていない。

ペッパーを圧力の異なる二酸化炭素で抽出した場合の 全抽出物とピペリンの収率を 図-2 $2^{8)}$ に示した。温度 60 ${ }^{\circ} \mathrm{C}$ で $3 \mathrm{~h}$ 抽出し, $55 \mathrm{bar}, 20^{\circ} \mathrm{C}$ で分離した結果である。 抽出圧力が低い場合には辛味成分は抽出されず精油分の みが抽出され，抽出圧力が高くなると全抽出物収率が増 加し，辛味成分であるピペリンも抽出されてくる。

図-3 $3^{7)}$ にはジンジャーの超臨界二酸化炭素及び塩化メ チレン抽出物のガスクロマトグラムを示した。図-3（a） (b) のガスクロマトグラムのパターンはかなり類似して おり，350 kg/cm ${ }^{2}\left(50^{\circ} \mathrm{C}\right)$ の超臨界二酸化炭素は抽出特 性において塩化メチレンに匹敵すると考えられる。しか

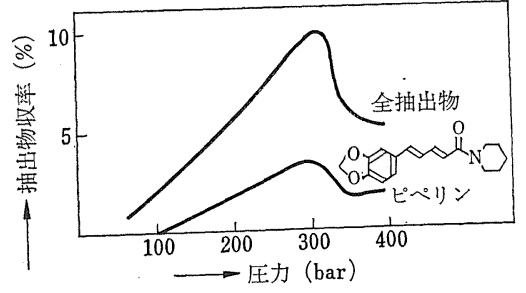

図-2 ペッパーの二酸化炭素抽出

表-5 スパイスの超臨界二酸化炭素抽出物と市販エキスの組成比較

\begin{tabular}{|c|c|c|c|c|c|}
\hline & \multicolumn{2}{|c|}{ 原料 $\mathrm{CO}_{2}$ 抽出 } & \multirow{2}{*}{$\begin{array}{c}\mathrm{CO}_{2} \\
\text { 抽出物 }\end{array}$} & \multirow{2}{*}{ 抽出率 } & \multirow{2}{*}{$\begin{array}{l}\text { 市 販 } \\
\text { エキス }\end{array}$} \\
\hline & （前） & (後) & & & \\
\hline 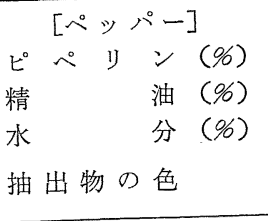 & $\begin{array}{r}10.1 \\
3.5 \\
9.3\end{array}$ & $\begin{array}{r}0.3 \\
<0.1 \\
6.2\end{array}$ & $\begin{array}{r}44.0 \\
12.7 \\
7.0 \\
\text { 黄 色 }\end{array}$ & $\begin{array}{l}97.7 \\
81.1\end{array}$ & $\begin{array}{r}41.2 \\
15.0 \\
0.2 \\
\text { オリーブ } \\
\text { グリーン }\end{array}$ \\
\hline $\begin{array}{l}\text { [ナツメグ] } \\
\text { 精 } \\
\text { ヘキサン可溶部 }(\%) \\
\text { 水 } \quad \text { 分 }(\%) \\
\text { 抽出物の色 } \\
\end{array}$ & $\begin{array}{r}7.4 \\
46.0 \\
4.9\end{array}$ & $\begin{array}{r}<0.1 \\
1.7 \\
4.4\end{array}$ & $\begin{array}{c}19.0 \\
100 \\
1.6 \\
\text { 黄白色 } \\
\end{array}$ & $\begin{array}{l}99.0 \\
98.0\end{array}$ & $\begin{array}{c}20.0 \\
100 \\
0.1 \\
\text { 黄褐色 }\end{array}$ \\
\hline $\begin{array}{l}\text { [チリペッパー }] \\
\text { カプサイシン }(\%) \\
\text { 水 分 }(\%) \\
\text { 抽出物の色 }\end{array}$ & $\begin{array}{l}0.86 \\
3.2\end{array}$ & $\begin{array}{l}0.03 \\
1.8\end{array}$ & $\begin{array}{r}4.9 \\
1.3 \\
\text { 赤 色 } \\
\end{array}$ & 97.0 & $\begin{array}{r}4.7 \\
0.1 \\
\text { 赤 色 } \\
\end{array}$ \\
\hline
\end{tabular}

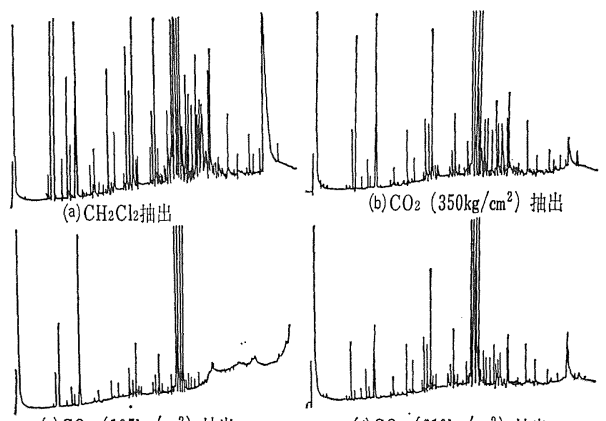

(c) $\mathrm{CO}_{2}\left(105 \mathrm{~kg} / \mathrm{cm}^{2}\right)$ 抽出

(d) $\mathrm{CO}_{2}{ }^{\circ}\left(210 \mathrm{~kg} / \mathrm{cm}^{2}\right)$ 抽出

図-3 ジンジャーの超臨界二酸化炭素及び塩化メチ レン抽出物のガスクロマトグラフィー

表-6 ジンジャーの超臨界二酸化炭素抽出圧力差 による抽出物収率の差

\begin{tabular}{l|c|c|c}
\hline 圧 力 & ジンジャー使用量 & 抽出物量 & 収 率 \\
\hline $350 \mathrm{~kg} / \mathrm{cm}^{2}$ & $30.24 \mathrm{~g}$ & $2.74 \mathrm{~g}$ & $9.1 \%$ \\
$105 \mathrm{~kg} / \mathrm{cm}^{2}$ & $32.44 \mathrm{~g}$ & $0.35 \mathrm{~g}$ & $1.1 \%$ \\
$210 \mathrm{~kg} / \mathrm{cm}^{2}$ & 同上* & $1.74 \mathrm{~g}$ & $5.4 \%$ \\
\hline
\end{tabular}

$* 105 \mathrm{~kg} / \mathrm{cm}^{2}$ 抽出に続く 2 回目抽出

し二酸化炭素抽出物の色調は黄緑色であり，塩化メチレ ン抽出物は暗緑色であった。さらに抽出圧力の違いによ る二酸化炭素の溶解力の差をみるため, $105 \mathrm{~kg} / \mathrm{cm}^{2}$ での 抽出が行われた。その抽出物は無色に近い液体であり, そのガスクロマトグラムは 図-3 (c) に示した。105kg/ $\mathrm{cm}^{2}$ での抽出物は $350 \mathrm{~kg} / \mathrm{cm}^{2}$ の場合に比べ低揮発性成 分をあまり多く含んでいない。図-3 (d) は先の $105 \mathrm{~kg} /$ $\mathrm{cm}^{2}$ での抽出残分をさらに $210 \mathrm{~kg} / \mathrm{cm}^{2}$ の圧力で抽出し たもののガスクロマトグラムである。この抽出物には $105 \mathrm{~kg} / \mathrm{cm}^{2}$ での抽出物中に多く存在する二, 三の揮発 性の高い成分が減少しているものの中〜低揮 発性成分がかなり含まれていた。

表-67)には上述したような圧力条件下で抽 出した場合の抽出物収率を示した。超臨界条 件では抽出圧力の違いにより抽出力にかなり の差が生じ，異なった性状の抽出物が得られ る。

表-7 ${ }^{8)}$ には 5 種のスパイスの超臨界あるい は液体二酸化炭素による抽出例を示した。こ の例では一定条件下で抽出後，3段階に設定 された分離条件下で抽出物の分離が行われ た。これらの例では各スパイスの精油分が比 較的効率よく抽出されている。これらのう ち，クローブとシナモンの抽出物の精油組成 を表-88)，-98) に示した。クローブの場合， 二酸化炭素抽出物は水蒸気蒸留精油ときわめ て類似した組成を示しており，シナモンの二 酸化炭素抽出物では水蒸気蒸留精油に比べモ 
変-7 スパイスの超臨界または液体二酸化炭素による抽出：分画分離による抽出物収率

\begin{tabular}{|c|c|c|c|c|c|c|c|c|c|}
\hline & $\begin{array}{l}\text { 原 料 } \\
\text { 精油含量* } \\
(\%)\end{array}$ & $\begin{array}{l}\text { 原料の石油エ } \\
\text { 二ル可溶成 } \\
\text { 分** }(\%) \quad(\%)\end{array}$ & $\begin{array}{l}\text { 抽出条件 } \\
\text { 圧力 } / / \text { 温度 }^{(\mathrm{bar}) /\left({ }^{\circ} \mathrm{C}\right)}\end{array}$ & $\begin{array}{l}\text { 分離条 } \\
1 \text { 段目 }\end{array}$ & $\begin{array}{l}\text { f: 圧 } \\
2 \text { (bar } \\
2 \text { 段目 }\end{array}$ & $\begin{array}{l}/ \text { 温度 } \\
\left({ }^{\circ} \mathrm{C}\right) \\
3 \text { 段目 }\end{array}$ & $\begin{array}{c}\text { そのらちの } \\
1 \text { 段目 }\end{array}$ & 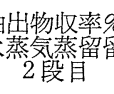 & $\begin{array}{l}\text { 城分(\%) } \\
3 \text { 段目 }\end{array}$ \\
\hline \multirow[t]{2}{*}{$r=x$} & \multirow[t]{2}{*}{2.1} & 14.7 & $90 / 40$ & $75 / 40$ & $30 / 0$ & - & $0.7(80)$ & $1.3(85)$ & - \\
\hline & & & 次いで 300/40 & $75 / 40$ & $40 / 5$ & - & 9.7 & 0.2 & - \\
\hline スターアニス & 4.2 & 10.6 & $90 / 20$ & $90 / 50$ & $80 / 55$ & $30 / 0$ & $3.4(5)$ & $0.7(76)$ & $2.8(90)$ \\
\hline キャラウェー & 4.1 & 14.1 & $90 / 20$ & $90 / 40$ & $75 / 40$ & $30 / 0$ & 3.8 (1) & $0.8(38)$ & $3.7(90)$ \\
\hline \multirow[t]{2}{*}{ クローブ } & \multirow[t]{2}{*}{19.0} & \multirow[t]{2}{*}{22.7} & $90 / 40$ & $85 / 40$ & $30 / 0$ & - & $2.9(75)$ & $13.6(82)$ & - \\
\hline & & & $90 / 0$ & $90 / 40$ & $70 / 40$ & $30 / 0$ & 0.1 (1) & $12.6(81)$ & $4.1(82)$ \\
\hline \multirow[t]{2}{*}{ シナモン } & \multirow[t]{2}{*}{1.5} & \multirow[t]{2}{*}{2.7} & $100 / 40$ & $85 / 40$ & $50 / 20$ & $30 / 0$ & 0.1 & 1.4 & 0.2 \\
\hline & & & $90 / 0$ & $85 / 40$ & $75 / 40$ & $30 / 0$ & 0.7 & 0.6 & 1.1 \\
\hline
\end{tabular}

* 水蒸気蒸留法により測定

** 石油エーテル (bp $\left.40 \sim 60^{\circ} \mathrm{C}\right)$, ソックスレー抽出により測定

表-8 クローブの二酸化炭素抽出物と水蒸気蒸留精油 の組成比較

\begin{tabular}{|c|c|c|}
\hline & $\begin{array}{c}\text { 永蒸 氮 } \\
\text { 蒸留 } \\
\text { (\%) }\end{array}$ & $\begin{array}{c}\text { 二酸华炭素 } \\
\text { (崖) }\end{array}$ \\
\hline カリオフィレン & 7.5 & 10.8 \\
\hline フ ム レ ン & 0.8 & 1.1 \\
\hline オイゲノール & 69.0 & 65.0 \\
\hline アセトオイゲノール & 21.0 & 18.0 \\
\hline
\end{tabular}

表-9 シナモンの二酸化炭素抽出物と水蒸気蒸留 精油の組成比較

\begin{tabular}{|c|c|c|}
\hline & $\begin{array}{l}\text { 水蒸気蒸留 } \\
\text { 精 } \\
(\%)\end{array}$ & $\begin{array}{c}\text { 二酸化炭素 } \\
\text { 抽 } \\
(\%)\end{array}$ \\
\hline モノテルペン & 13 & 5 \\
\hline セスキテルペン & 6 & 7 \\
\hline 含酸素モノテルペン & 4 & 3 \\
\hline シンナムアルデヒド & 64 & 74 \\
\hline オイゲノール & 1.5 & 1 \\
\hline $\begin{array}{l}o \text { oメトキシシンナム } \\
\text { アルデヒド }\end{array}$ & 5.5 & 5 \\
\hline
\end{tabular}

ノテルペン含量が少なくシンナムアルデヒド含量が多か った。表-7 に示した各条件で抽出・分離された抽出物 は，水蒸気蒸留により得られた精油に比べ香気良好であ り，適切な抽出・分離条件を選択することにより，スパ イスから二酸化炭素抽出で高品質の精油が得られること が示された。

スパイスの抽出においては液体二酸化炭素を用いても 精油成分はかなり効率よく抽出され，超臨界条件下では 精油成分とともに呈味成分も抽出される。またスパイス を超臨界二酸化炭素で抽出するに際し，１回目の抽出を 乾燥した二酸化炭素で実施し，主に精油成分を抽出し， 2 回目の抽出ではエントレーナーに水を用い湿った二酸 化炭素で抽出を行うと呈味成分がより効率よく抽出され るともされている9)。
表-10 レモン果皮の超臨界二酸化炭素抽出オイルと コールドプレスオイルの組成比較

\begin{tabular}{|c|c|c|}
\hline & $\mathrm{CO}_{2}$ 抽出物 & $\begin{array}{l}\text { コールドプレス } \\
\text { オイル }(\%)\end{array}$ \\
\hline モノテルペン類 & 92.40 & 95.00 \\
\hline リ モ ネン & 62.90 & 66.60 \\
\hline ネ ラーール & 0.30 & 1.20 \\
\hline ゲ ラ & 0.20 & 1.15 \\
\hline$\alpha$-テルピネオール & 1.20 & 0.25 \\
\hline シトロネロール & - & 0.40 \\
\hline ネローール & 0.80 & 0.01 \\
\hline ゲラニオール & 1.30 & 0.03 \\
\hline ネリル アセテート & 0.45 & 0.40 \\
\hline ゲラニル アセテート & 0.45 & 0.35 \\
\hline
\end{tabular}

\section{4 フルーツ香気成分の抽出}

超臨界二酸化炭素によるレモン果皮からの精油の抽出 が試みられている ${ }^{6)}$ 。抽出は 300 bar, $40^{\circ} \mathrm{C}$ で行われ， 精油収率は $0.9 \%$ であった。表-10 には超臨界二酸化 炭素抽出によるオイルと, コールドプレス法によるオイ ルの組成の比較を示した。リモネンを含むモノテルペン 含量は両者のオイルで大差なく，またネリルアセテー ト，ゲラニルアセテート含量もほぼ同じであった。両者 のオイルの組成にはアルデヒドとアルコール含量に顕著 な差があり，超臨界二酸化炭素抽出オイルにはネラー ル，ゲラニアールが少なく，ネロール，ゲラニオール， $\alpha$-テルピネオールのような テルペンアルコール 類の多 いのが特徵であった。

$\mathrm{C}_{6} \sim \mathrm{C}_{8}$ のアルコール，アルデヒド， エステルから組 み立てた合成アップルエッセンスを用いての超臨界二酸 化炭素抽出検討も行われた 成アップルエッセンス, 図-4 (b) はその超臨界二酸化 炭素抽出物のガスクロマトグラムである。両者は若干の 差があるものの全体的にはほぼ同じパターンを示してい る。図-4 (c) は二酸化炭素抽出残分のガスクロマトグ ラムであり，すべての成分濃度は減少しており，この合 


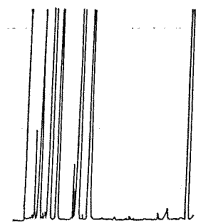

(a)原エッセンス

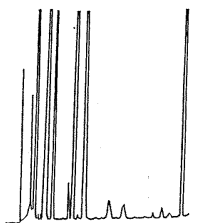

(b) $\mathrm{CO}_{2}$ 抽出物

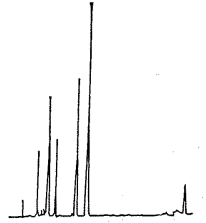

(c) $\mathrm{CO}_{2}$ 抽出残分
図-4：合成アップルエッセンスの超臨界 二酸化炭素抽出

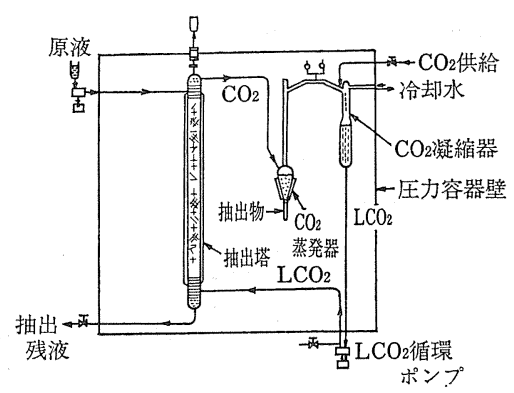

図-5 液体二酸化炭素による液-液抽出装置

成アップレエッセンスつ且女立てこ用いられた化合物 は超臨界二酸化炭素により効率よく抽出されていること がわかる。

フルーツの香気成分は, 上述のよらに超臨界二酸化炭 素で抽出されるが, 液体二酸化炭素でも効率よく抽出さ れることが知られている。果汁，エッセンズかの液体 二酸化炭素による香気成分の抽出には 図-5 に示したよ うな液一液抽出装置が用いられた ${ }^{10) 。}$

アップル，パイナップル，グレープ，ペアーなどを用 いての実験では，いずれの場合にもそれらの香気成分が 効率よく抽出されうることが示されている11。

アップルエッセンスを用い, 液体二酸化炭素, イソペ ンタン, エーテル, フッ化炭化水素を溶剤とした各抽出 物の比較では, 液体二酸化炭素による抽出物の組成はエ ーテル抽出物のものとかなり類似していた

図-6 ${ }^{11)}$ にはパイナップルエッセンスとその液体二酸化 崖素抽出物のガスクロマトグラムを示した。パイナップ ルエッセンスの液体二酸化炭素による短時間抽出物は芳 香性の強い顕著なパイナップル香気 を示した。原パイナップルエッセン スのガスクロマトグラムの相対保持 時間の短い部分は多量に存在するエ タノールと酢酸エチルによるもので あるが，これらの成分はパイナップ ル香気への寄与は小さく，液体二酸 化炭素抽出物での存在量は少なくな っている。両者のガスクロマトグラ ムのピークの比較から抽出物は原エ

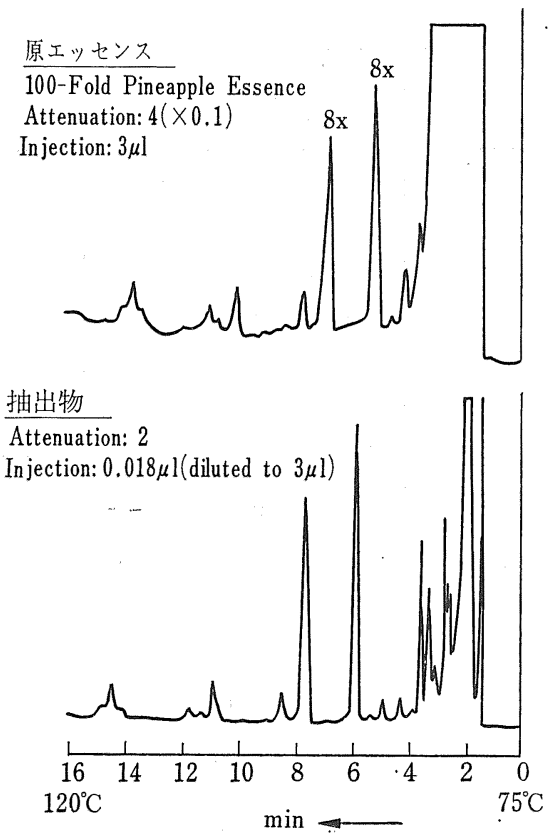

図-6 パイナップルエッセンスとその液体二酸化 炭素抽出物のガスクロマトグラム

ッセンスの約 $500 \sim 1,000$ 倍に濃縮されていることが示 された。

\section{5 その他の香料関連物質抽出への応用}

ワインを蒸留しブランディーやスピリットを得る場 合, 蒸留に先立ちフレーバー成分を液体二酸化炭素で抽 出し, 回収したフレーバーをワインに添加しフレーバー 強化されたワインを調製しようという試みがなされた $\left(\right.$ 図-7 ${ }^{13)}$ 。

$23 l$ の白ワインから約 $45 \%$ のエタノールを含む 37 $\mathrm{ml}$ のフレーバー濃縮物が得られ，これを通常のテーブ ルワインに $0.1 \%$ 添加したところ 顕著にフレーバーが 強化され品質が改善された。

超臨界二酸化炭素によるライラックの花の香気成分の 抽出も検討された。ライラックの花は独特の芳香を示す が，水蒸気蒸留により得られる精油は花の香気とはやや

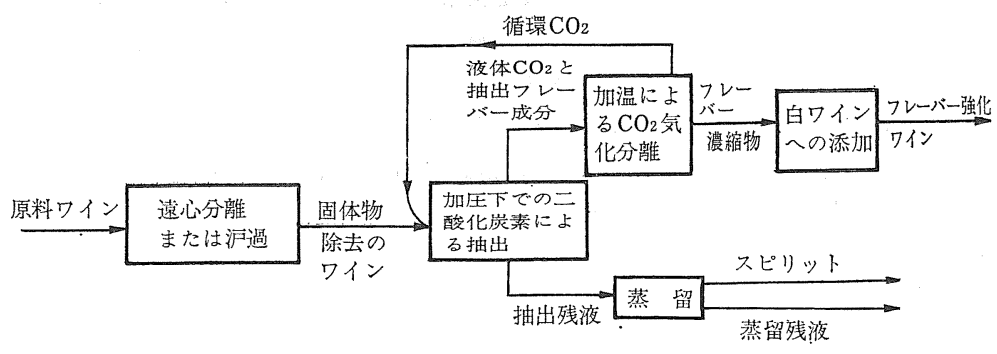

図-7 ワインフレーバーの液体二酸化炭素抽出とその利用 


\begin{tabular}{|c|c|c|}
\hline 表-11 & \multicolumn{2}{|c|}{$\begin{array}{l}\text { ライラックの花の超臨界 } \\
\text { 二酸化岸素抽出物の揮発 } \\
\text { 性成分組成 }\end{array}$} \\
\hline \multicolumn{2}{|c|}{ ベンジルベンゾエート } & $32.6 \%$ \\
\hline$I \quad V$ & ミシン & $14.6 \%$ \\
\hline \multirow{2}{*}{\multicolumn{2}{|c|}{$\begin{array}{l}\text { ライラックアルコール } \\
\text { ベンジルアルコール }\end{array}$}} & $9.8 \%$ \\
\hline & & $7.3 \%$ \\
\hline $7 \quad 1$ & ト $ー ル$ & $7.8 \%$ \\
\hline \multicolumn{2}{|c|}{ シンナミルアルコール } & $4.1 \%$ \\
\hline へキサ & デカナール & $3.2 \%$ \\
\hline
\end{tabular}

異なっており，こ れは水蒸気蒸留で は成分の一部が分 解されるか蒸留さ れ難いためと考元 られる。ライラッ クの花を $90 \mathrm{bar}$, $34^{\circ} \mathrm{C}$ の超臨界二 酸化炭素で抽出 ᄂ, $35 \mathrm{bar}, 14^{\circ} \mathrm{C}$

で分離を行ったとこちライラックの特徵的な香気をもっ た抽出物が得られた ${ }^{6)}$ 。抽出物はほとんど固体に近い状 態のものであり，これを脱ワックスしアブソリユートと したものの GC-MS 分析結果を 表-11 に示した。興味 ある点は，過去に種々の方法でライラックの花の香気成 分を単離, 分析した結果ではここに示したライラックア ルコール以外の成分のどれも見いだされていなかったこ とである。

\section{6 おわりに}

香料関連物質の超臨界または液体二酸化炭素による抽 出と, 従来の水蒸気蒸留, 溶剤抽出とを比較すると, 二 酸化炭素抽出法には一般的に次のような利点があると考 えられる。

1）比較的低温での抽出, 分離操作が可能なため, 香 気成分の熱変化が起こり難い。

2）二酸化炭素による不活性ガス雰囲気下で操作が行 われるため香気成分の酸化，変質が起こり難い。

3）温度, 圧力の制御により, 抽出物からの脱溶倣が

容易に行われ，かつ二酸化炭素が無毒性のため残存 溶剤レベルが問題とならない。

超臨界または液体二酸化炭素による香料関連物質の抽 出としては, 既にスパイス, ホップについて実用化の域 に達している。しかし今後, これらの抽出技術が広く工 業的レベルで香料関連物質の抽出に用いられるためには さらに個々のケースについて充分な検討, 評価がなされ ねばならないと考える。

(昭和 61 年 2 月 6 日受理)

\section{文献}

1) H. Brogle, Chem. Ind. (London), 1982 (19), 385

2) P. Huber, O.G. Vitzthum, Angere. Chem. Int. Ed. Engl., 17, 710 (1978)

3) F.V. Harold, B.J. Clarke, Brew. Digest, 1979 (Sep.), 45

4) D.R.J. Laws, N.A. Bath, J.A. Pickett, J. Inst. Brere., 83, 39 (1977)

5) R. Vollbrecht, Chem. Ind., (London), 1982 (19), 397

6) J.P. Calame, R. Steiner, Chem. Ind. (London), 1982, (19) 399

7) V.J. Krukonis, ACS Annual Meeting (Agr. Food Div.) Philadelphia, Pennsylvania, Aug. 1984

8) E. Stahl, D. Gerard, Parfüm. Kosm., 63, 117 (1982)

9）特許出願公告 昭 $55-35,091$

10) W.G. Schultz, T.H. Schultz, R.A. Carlson, J.S. Hu= dson, Food Technol., 28, 32 (1974)

11) J.M. Randall, W.G. Schultz, A.I. Morgan, Confurcta, 16, 10 (1971)

12) T.H. Schultz, R.A. Flath, D.R. Black, D.G. Guada= gni, W.G. Schultz, R. Teranishi, J. Food Sci., 32, 279 (1967)

13) D.R.P. Jolly, Process Biochem., 1981 (Aug/Sep), 36 